\title{
Korelasi Derajat Leukoaraiosis dengan Faktor-faktor Risiko Stroke dan Keparahan Stroke Berdasarkan Derajat Klinis pada Pasien Stroke Iskemik
}

\section{Correlation Between the Degree of Leukoaraiosis with the Stroke Risk Factors and the Severity of Stroke Based on Clinical Degree in Ischemic Stroke Patients}

\author{
Yohanes Irsandy ${ }^{1}$, Sri Asriyani ${ }^{2}$, Bachtiar Murtala ${ }^{2}$, Burhanuddin Bahar ${ }^{3}$, Ashari Bahar ${ }^{4}$, \\ Nurlaily Idris ${ }^{2}$ \\ ${ }^{1}$ Resident of Radiology Department, Faculty of Medicine, Hasanuddin University, Makassar \\ ${ }^{2}$ Radiology Department, Faculty of Medicine, Hasanuddin University, Makassar \\ ${ }^{3}$ Public Health Department, Faculty of Medicine, Hasanuddin University, Makassar \\ ${ }^{4}$ Neurology Department, Faculty of Medicine, Hasanuddin University, Makassar \\ Correspondence Email: yohanesirsandy@yahoo.com
}

\section{KATA KUNCI Leukoaraiosis; Stroke Iskemik; Skala Van Swieten; NIHSS}

\begin{abstract}
ABSTRAK
Penelitian ini bertujuan mengetahui korelasi derajat leukoaraiosis berdasarkan CT-Scan kepala dengan faktor-faktor risiko stroke dan keparahan stroke berdasarkan derajat klinis pada pasien stroke iskemik. Metode yang digunakan adalah cross sectional, dilakukan secara retrospektif pada penderita stroke iskemik yang menjalani pemeriksaan CT-Scan kepala di Bagian Radiologi RSUP dr. Wahidin Sudirohusodo, Makassar periode Januari 2020 sampai Juli 2020. Sampel sebanyak 46 orang dengan usia >40 tahun yang mengalami serangan stroke pertama dengan onset $<1$ bulan. Derajat leukoaraiosis dinilai dengan menggunakan skala Van Swieten dan derajat klinis dinilai dengan menggunakan National Institute of Health Stroke Scale (NIHSS). Uji statistik yang digunakan adalah uji korelasi Spearman. Hasil penelitian menunjukkan bahwa ada korelasi bermakna yang sedang dan searah antara derajat leukoaraiosis dan kelompok umur dengan nilai p sebesar 0,004 (<0,05) dan nilai $r$ sebesar 0,415. Tidak ada korelasi bermakna antara derajat leukoaraiosis dengan jenis kelamin, hipertensi, diabetes melitus, dislipidemia dan derajat klinis dengan nilai p masing-masing secara berurutan sebesar 0,146; 0,520; 0,779; 0,185; dan 0,537 (>0,05). Namun tampak kecenderungan bahwa pasien dengan hipertensi tidak terkontrol memiliki derajat leukoaraiosis yang lebih berat.
\end{abstract}


ABSTRACT This study aims to determine the correlation between the degree of leukoaraiosis based on head CT scan with the stroke risk factors and the severity of stroke based on clinical degree in ischemic stroke patients. The study used Cross-sectional approach, conducted retrospectively on ischemic stroke patients who underwent a head CT scan at the radiology department of $d r$. Wahidin Sudirohusodo General Hospital, Makassar for the period of January 2020 to July 2020. The sample was 46 people aged $>40$ years who had their first stroke with an onset of $<1$ month. The degree of leukoaraiosis was assessed using the Van Swieten scale and the clinical degree was assessed using the National Institute of Health Stroke Scale (NIHSS). The statistical method used was the Spearman correlation test. The results show that there is a moderate and unidirectional significant correlation between the degree of leukoaraiosis and the age group with a p value of 0.004 $(<0.05)$ and an $r$ value of 0.415. There is no significant correlation between the degree of leukoaraiosis with gender, hypertension, diabetes mellitus, dyslipidemia and clinical degree with $p$ values respectively 0.146; 0.520; 0.779; 0.185; and 0.537 (> 0.05). However, it appears that patients with uncontrolled hypertension have a heavier degree of leukoaraiosis.

\section{PENDAHULUAN}

Leukoaraiosis adalah gambaran patologis dari materi putih otak, yang telah lama diyakini disebabkan oleh gangguan perfusi dalam arteriol yang menembus struktur otak dalam. Karena etiopatogenesis dan relevansi klinis yang kompleks, leukoaroisosis telah diselidiki dalam banyak penelitian. Perihal implikasi klinis dari leukoaraiosis, temuan neuroimaging ini sangat terkait dengan stroke iskemik, perjalanan stroke iskemik yang tidak menguntungkan pada fase akut, hasil jangka panjang yang lebih buruk, dan gangguan kognitif (Marek et al., 2018).

Perubahan materi putih muncul sebagai area atenuasi rendah pada CT dan area dengan sinyal tinggi pada T2weighted atau MRI FLAIR. MRI lebih sensitif daripada CT dalam mendeteksi lesi kecil, sementara lesi yang lebih besar dideteksi sama baiknya dengan kedua metode pencitraan (Grueter and Schulz, 2012).

Berdasarkan neuroimaging, keparahan leukoaraiosis dapat dinilai menggunakan berbagai skala. Namun, skala Van Swieten untuk CT dan Fazekas untuk MRI menjadi yang paling umum digunakan dalam praktek klinis (Marek et al., 2018).

Stroke secara klasik ditandai sebagai defisit neurologis yang disebabkan oleh cedera fokus akut pada susunan saraf pusat (SSP) oleh penyebab vaskular, termasuk infark, perdarahan intraserebral (PIS), dan perdarahan subarakhnoid (PSA), dan merupakan penyebab utama kecacatan dan kematian di seluruh dunia (Sacco et al., 2013).

Keparahan defisit neurologi terkait stroke dinilai menggunakan The National 
Institutes of Health Stroke Scale (NIHSS) (Lyden, 2017).

Terdapat beberapa penelitian sebelumnya yang mengorelasikan derajat leukoaraiosis dengan keparahan stroke, diantaranya adalah penelitian Arsava E.M. et al yang menunjukkan bahwa volume leukoaraiosis berkorelasi dengan keparahan stroke (Arsava et al., 2009).

Penelitian Helenius J. et al yang menunjukkan hubungan antara derajat leukoaraiosis dan volume infark serta keparahan klinis stroke dalam NIHSS (Helenius and Henninger, 2015).

Penelitian Marek M. et al pada tahun 2015 yang menunjukkan luas leukoaraiosis sangat berkorelasi dengan gambaran stroke iskemik dan perjalanannya (Marek et al., 2017).

Namun, penelitian terbaru yang dilakukan oleh Marek M. et al menunjukkan derajat leukoaraiosis tidak memiliki pengaruh pada keparahan stroke dalam skala NIHSS (Marek et al., 2019).

Berdasarkan latar belakang di atas maka penulis ingin melakukan penelitian ini untuk membuktikan sendiri korelasi derajat leukoaraiosis berdasarkan CTscan dengan keparahan stroke berdasarkan klinis pada pasien dengan stroke iskemik.

\section{METODOLOGI}

Desain penelitian ini adalah observasi cross sectional, sampel diambil secara consecutive sampling, dari hasil perhitungan diperoleh besar sampel minimal pada penelitian ini adalah 32 orang. Subjek pada penelitian ini adalah pasien stroke iskemik dengan usia $>40$ tahun yang mengalami serangan stroke pertama kali dengan onset $<1$ bulan yang datang ke bagian Radiologi untuk menjalani pemeriksaan CT-scan kepala pada periode Januari 2020 sampai Juli 2020. Kriteria eksklusi penelitian ini yaitu penderita stroke iskemik yang disertai pendarahan, tumor otak, infeksi otak, hidrosefalus, encephalomalacia dan atrial fibrilasi.

Data karakteristik sampel, riwayat hipertensi, riwayat DM dan riwayat dislipidemia diperoleh dari rekam medis pasien.

Derajat leukoaraiosis dinilai menggunakan skala Van Swieten. Dalam skala ini, bagian anterior dan posterior dari setiap irisan otak dievaluasi secara terpisah pada tingkat pleksus vaskular dari kornu posterior ventrikel, bagian tengah ventrikel lateral, dan korona radiata, skor penilaian sesuai dengan berikut ini : 0 tidak ada lesi, 1 - keterlibatan sebagian materi putih, dan 2 - meluas sampai area subkortikal; dengan skor maksimum adalah 4 untuk bagian anterior dan posterior (Marek et al., 2018) (Gambar 1). Derajat klinis dinilai menggunakan National Institute of Health Stroke Scale (NIHSS) yang terdiri dari 11 item, masing-masing menilai kemampuan spesifik antara 0 sampai 4 . Untuk setiap item, skor 0 biasanya menunjukkan fungsi normal dalam kemampuan spesifik tersebut, sementara skor yang lebih tinggi menunjukkan penurunan kemampuan. Skor dari setiap item dijumlahkan untuk menghitung skor total NIHSS. pasien yang kemudian digolongkan dengan batasan nilai >25 sangat berat, 16-25 berat, 5-15 sedang, dan nilai $<5$ ringan.

Analisis data terdiri dari analisis deskriptif dan uji korelasi Spearman menggunakan program SPSS versi 25 . Hasil uji korelasi Spearman dikatakan ada hubungan kesesuaian yang bermakna secara statistik jika nilai $\mathrm{p}<0,05$. 

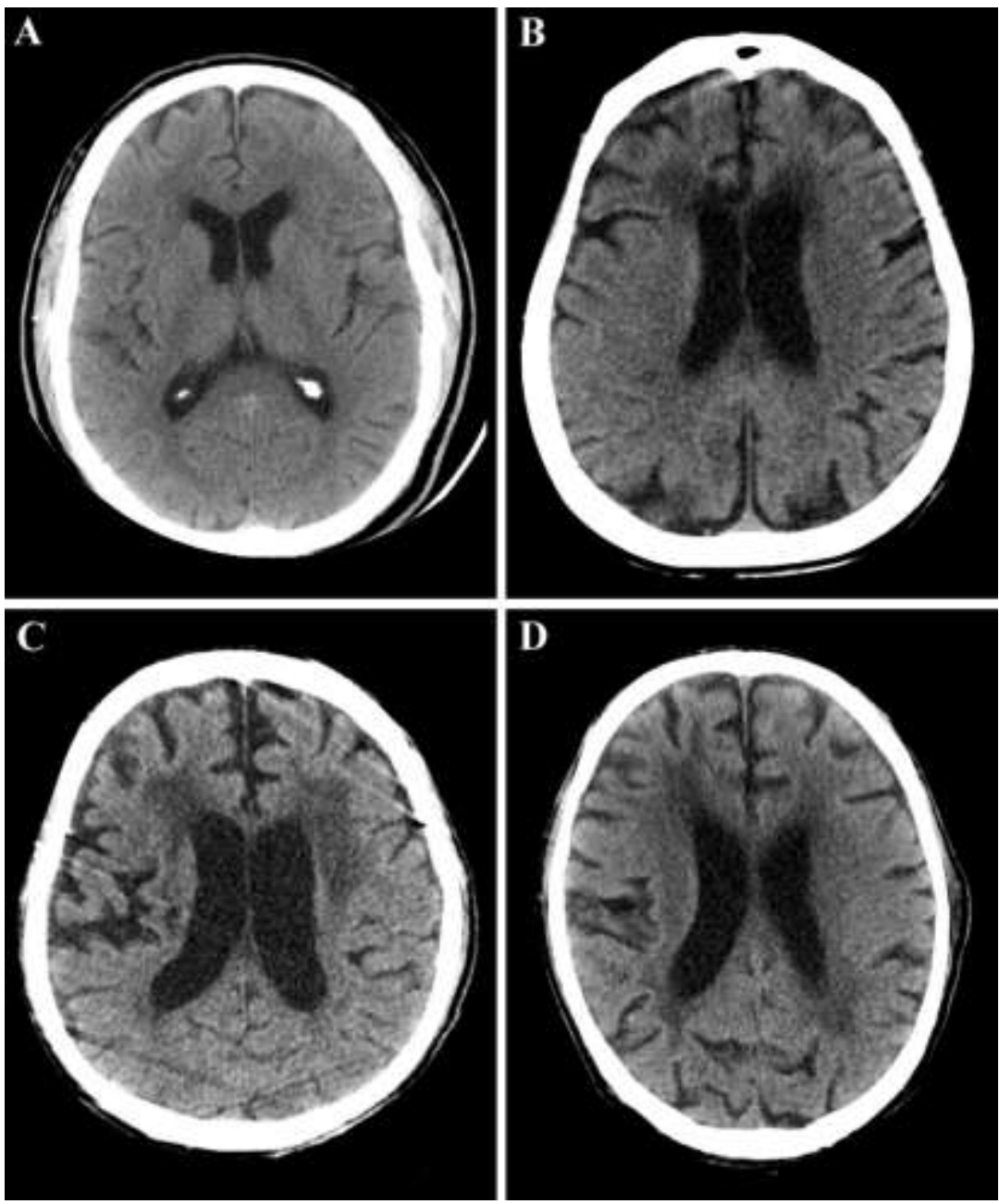

Gambar 1. Skala Van Swieten. CT-scan otak pada level sistem ventrikel menunjukkan tingkat keparahan masing-masing leukoaraiosis. A) Derajat 1 - lesi hipodens kecil di sekitar kornu anterior ventrikel lateral. B) Derajat 2 - lesi hipodens konfluen yang difus di sekitar kornu anterior ventrikel lateral yang meluas ke korteks serebral. C) Derajat 3 lesi hipodens konfluen yang difus di sekitar kornu anterior ventrikel lateral yang meluas ke korteks serebral dan lesi hipodens kecil di sekitar kornu posterior ventrikel lateral. D) Derajat 4 - lesi hipodens konfluen yang difus di sekitar cornu anterior dan posterior ventrikel lateral. 
ISI

Penelitian ini dilakukan secara cross sectional di bagian Radiologi Sentral RSUP Dr. Wahidin Sudirohusodo Makassar pada bulan Juli 2020 sampai Agustus 2020, didapatkan sebanyak 46 sampel yang memenuhi kriteria.

Tabel 1. Karakteristik sampel

\begin{tabular}{lcc}
\hline \multicolumn{1}{c}{ Karakteristik } & $\mathrm{N}$ & $\%$ \\
\hline Jenis Kelamin & & \\
Laki-laki & 24 & 52,2 \\
Perempuan & 22 & 47,8 \\
Umur & & \\
$41-50$ thn & 16 & 15,2 \\
$51-60$ thn & 12 & 34,8 \\
61-70 thn & 9 & 26,1 \\
71-80 thn & 2 & 19,6 \\
$81-90$ thn & & 4,3 \\
Hipertensi & 5 & 10,9 \\
Tidak ada & 11 & 23,9 \\
Ada, terkontrol & 30 & 65,2 \\
Ada, tidak & & \\
terkontrol & & \\
DM & 29 & 63 \\
Tidak ada & 1 & 2,2 \\
Ada, terkontrol & 16 & 34,8 \\
Ada, tidak & & \\
terkontrol & 1 & 2,2 \\
Dislipidemia & 19 & 41,3 \\
Tidak ada & & \\
Ada & & \\
\hline
\end{tabular}

Distribusi berdasarkan jenis kelamin, penderita stroke iskemik sedikit lebih banyak ditemukan pada jenis kelamin laki-laki sebanyak $24 \quad(52,2 \%)$ sampel dibandingkan perempuan yaitu 22 $(47,8 \%)$ sampel.

Distribusi berdasarkan umur, penderita stroke iskemik lebih banyak ditemukan pada umur 51-60 tahun sebanyak $16(34,8 \%)$ sampel, ditemukan pada umur 61-70 tahun sebanyak 12 $(26,1 \%)$ sampel, ditemukan pada umur 7180 tahun sebanyak 9 (19,6\%) sampel, ditemukan pada umur 41-50 tahun sebanyak $7(15,2 \%)$ sampel, sedangkan lebih sedikit ditemukan pada umur 81-90 tahun sebanyak $2(4,3 \%)$ sampel.

Distribusi berdasarkan riwayat hipertensi, penderita stroke iskemik lebih banyak ditemukan pada yang memiliki riwayat hipertensi yang tidak terkontrol sebanyak $30(65,2 \%)$ sampel, ditemukan pada yang memiliki riwayat hipertensi yang terkontrol sebanyak $11 \quad(23,9 \%)$ sampel, sedangkan lebih sedikit ditemukan pada yang tidak memiliki riwayat hipertensi sebanyak 5 (10,9\%) sampel.

Distribusi berdasarkan riwayat DM, penderita stroke iskemik lebih banyak ditemukan pada yang tidak memiliki riwayat DM sebanyak 29 (63\%) sampel, ditemukan pada yang memiliki riwayat DM yang tidak terkontrol sebanyak $16(34,8 \%)$ sampel, sedangkan ditemukan pada yang memiliki riwayat DM yang terkontrol hanya sebanyak 1 $(2,2 \%)$ sampel.

Distribusi berdasarkan riwayat dislipidemia hanya terdapat 20 sampel yang ada datanya, penderita stroke iskemik lebih banyak ditemukan pada yang memiliki riwayat dislipidemia yaitu sebanyak 19 (41,3\%) sampel, ditemukan pada yang tidak memiliki riwayat dislipidemia yaitu sebanyak $1 \quad(2,2 \%)$ sampel, sedangkan $26(56,5 \%)$ sampel tidak ada datanya.

Tabel 2. Distribusi derajat leukoaraiosis

\begin{tabular}{ccc}
\hline Derajat leukoaraiosis & $\mathrm{N}$ & $\%$ \\
\hline 0 & 13 & 28,3 \\
1 & 14 & 30,4 \\
2 & 6 & 13 \\
3 & 6 & 13 \\
4 & 7 & 15,2 \\
\hline
\end{tabular}

Tabel 2 memperlihatkan distribusi sampel berdasarkan derajat leukoaraiosis. Penderita stroke iskemik lebih banyak 
ditemukan pada leukoaraiosis derajat 1 sebanyak $14(30,4 \%)$ sampel, sedikit lebih banyak daripada yang tidak ada leukoaraiosis sebanyak $13 \quad(28,3 \%)$ sampel, ditemukan pada leukoaraiosis derajat 4 sebanyak $7(15,2 \%)$ sampel, sedangkan sama-sama lebih sedikit ditemukan pada leukoaraiosis derajat 2 dan 3 sebanyak 6 (13\%) sampel.

Tabel 3. Distribusi derajat klinis

\begin{tabular}{ccc}
\hline Derajat klinis & N & $\%$ \\
\hline Ringan & 14 & 30,4 \\
Sedang & 27 & 58,7 \\
Berat & 4 & 8,7 \\
Sangat berat & 1 & 2,2 \\
\hline
\end{tabular}

Tabel 3 memperlihatkan distribusi sampel berdasarkan derajat klinis. Penderita stroke iskemik lebih banyak ditemukan pada derajat klinis sedang sebanyak 27 (58,7\%) sampel, ditemukan pada derajat klinis ringan sebanyak 14 $(30,4 \%)$ sampel, ditemukan pada derajat klinis berat sebanyak $4(8,7 \%)$ sampel, sedangkan lebih sedikit ditemukan pada derajat klinis sangat berat sebanyak 1 $(2,2 \%)$ sampel.

Tabel 4 memperlihatkan distribusi berdasarkan derajat leukoaraiosis dan jenis kelamin serta korelasinya menggunakan uji Spearman. Penderita stroke iskemik laki-laki lebih banyak memiliki derajat leukoaraiosis 1 yaitu sebanyak $6(25 \%)$ sampel dan penderita stroke iskemik perempuan lebih banyak memiliki derajat leukoaraiosis 0 dan 1 yaitu sama-sama sebanyak $8 \quad(36 \%)$ sampel. Hasil analisis korelasi diperoleh nilai $\mathrm{P}$ sebesar $0,146(>0,05)$ maka dapat disimpulkan bahwa tidak ada korelasi yang bermakna antara derajat leukoaraiosis dengan jenis kelamin.

Tabel 5 memperlihatkan distribusi berdasarkan derajat leukoaraiosis dan menggunakan uji Spearman. Penderita stroke iskemik kelompok umur 41-50 tahun dan 51-60 tahun sama-sama lebih banyak memiliki derajat leukoaraiosis 0 yaitu masing-masing sebanyak $5(71,4 \%)$ dan $6(37,5 \%)$ sampel, penderita stroke iskemik kelompok umur 61-70 tahun lebih

Tabel 4. Korelasi derajat leukoaraiosis dan jenis kelamin

\begin{tabular}{ccccccccc}
\hline \multirow{2}{*}{ Jenis Kelamin } & 0 & 1 & 2 & 3 & 4 & \multirow{2}{*}{ Total } & \multirow{2}{*}{ Nilai P } & \multirow{2}{*}{ Nilai r } \\
\hline Laki-laki & 5 & 6 & 5 & 4 & 4 & 24 & & \\
Perempuan & 8 & 8 & 1 & 2 & 3 & 22 & 0,146 & $-0,218$ \\
Total & 13 & 14 & 6 & 6 & 7 & 46 & & \\
\hline
\end{tabular}

Tabel 5. Korelasi derajat leukoaraiosis dan kelompok umur

\begin{tabular}{|c|c|c|c|c|c|c|c|c|}
\hline \multirow{2}{*}{ Kelompok Umur } & \multicolumn{5}{|c|}{ Derajat Leukoaraiosis } & \multirow{2}{*}{ Total } & \multirow{2}{*}{ Nilai P } & \multirow{2}{*}{ Nilai $r$} \\
\hline & 0 & 1 & 2 & 3 & 4 & & & \\
\hline 41-50 tahun & 5 & 0 & 2 & 0 & 0 & 7 & \multirow{6}{*}{0,004} & \multirow{6}{*}{0,415} \\
\hline 51-60 tahun & 6 & 5 & 0 & 3 & 2 & 16 & & \\
\hline 61-70 tahun & 1 & 7 & 0 & 2 & 2 & 12 & & \\
\hline $71-80$ tahun & 1 & 1 & 4 & 1 & 2 & 9 & & \\
\hline $81-90$ tahun & 0 & 1 & 0 & 0 & 1 & 2 & & \\
\hline Total & 13 & 14 & 6 & 6 & 7 & 46 & & \\
\hline
\end{tabular}


kelompok umur serta korelasinya banyak memiliki derajat leukoaraiosis 1 yaitu sebanyak $7(58,3 \%)$ sampel, penderita stroke iskemik kelompok umur 71-80 tahun lebih banyak memiliki derajat leukoaraiosis 2 yaitu sebanyak $4(44,4 \%)$ sampel, dan pada dua penderita stroke iskemik kelompok umur 81-90 tahun masing-masing memiliki derajat leukoaraiosis 1 dan 4. Hasil analisis korelasi diperoleh nilai $\mathrm{P}$ sebesar 0,004 $(<0,05)$ maka dapat disimpulkan bahwa ada korelasi yang bermakna antara derajat leukoaraiosis dengan kelompok umur dan memliki kekuatan korelasi sedang dan searah dengan nilai $r$ sebesar 0,415 .

Tabel 6 memperlihatkan distribusi berdasarkan derajat leukoaraiosis dan hipertensi serta korelasinya menggunakan uji Spearman. Penderita stroke iskemik yang tidak memiliki hipertensi lebih banyak memiliki derajat leukoaraiosis 0 dan 3 yaitu sama-sama sebanyak 2 (40\%) sampel, penderita stroke iskemik dengan hipertensi terkontrol lebih banyak memiliki derajat leukoaraiosis 1 yaitu sebanyak $6(54,6 \%)$ sampel dan penderita stroke iskemik dengan hipertensi tidak terkontrol lebih banyak memiliki derajat leukoaraiosis 0 yaitu sebanyak 9 (30\%) sampel. Hasil analisis korelasi diperoleh nilai $\mathrm{P}$ sebesar 0,520 $(>0,05)$ maka dapat disimpulkan bahwa tidak ada korelasi yang bermakna antara derajat leukoaraiosis dengan hipertensi.

Tabel 7 memperlihatkan distribusi berdasarkan derajat leukoaraiosis dan DM serta korelasinya menggunakan uji Spearman. Penderita stroke iskemik yang tidak memiliki DM lebih banyak memiliki derajat leukoaraiosis 1 yaitu sebanyak 11 $(37,9 \%)$ sampel, penderita stroke iskemik dengan DM terkontrol hanya terdapat 1 sampel dengan derajat leukoaraiosis 2 dan penderita stroke iskemik dengan DM tidak terkontrol lebih banyak memiliki derajat leukoaraiosis 0 yaitu sebanyak $5(31,3 \%)$ sampel. Hasil analisis korelasi diperoleh nilai $\mathrm{P}$ sebesar $0,779(>0,05)$ maka dapat disimpulkan bahwa tidak ada korelasi yang bermakna antara derajat leukoaraiosis dengan DM.

Tabel 6. Korelasi derajat leukoaraiosis dan hipertensi

\begin{tabular}{ccccccccc}
\hline \multirow{2}{*}{ Hipertensi } & 0 & \multicolumn{9}{c}{ Derajat Leukoaraiosis } & \multirow{2}{*}{ Notal } & \multirow{2}{*}{ Nilai P } & \multirow{2}{*}{ Nilai r } \\
\hline Tidak ada & 2 & 1 & 0 & 2 & 0 & 5 & & \\
Ada, terkontrol & 2 & 6 & 2 & 0 & 1 & 11 & & \multirow{2}{*}{0,097} \\
Ada, tidak & 9 & 7 & 4 & 4 & 6 & 30 & & \\
terkontrol & 13 & 14 & 6 & 6 & 7 & 46 & & \\
Total & 13 & & & & & & & \\
\hline
\end{tabular}

Tabel 7. Korelasi derajat leukoaraiosis dan DM

\begin{tabular}{|c|c|c|c|c|c|c|c|c|}
\hline \multirow{2}{*}{$\mathrm{DM}$} & \multicolumn{5}{|c|}{ Derajat Leukoaraiosis } & \multirow{2}{*}{ Total } & \multirow{2}{*}{ Nilai P } & \multirow{2}{*}{ Nilai $r$} \\
\hline & 0 & 1 & 2 & 3 & 4 & & & \\
\hline Tidak ada & 8 & 11 & 2 & 3 & 5 & 29 & \multirow{4}{*}{0,779} & \multirow{4}{*}{0,042} \\
\hline Ada, terkontrol & 0 & 0 & 1 & 0 & 0 & 1 & & \\
\hline $\begin{array}{l}\text { Ada, tidak } \\
\text { terkontrol }\end{array}$ & 5 & 3 & 3 & 3 & 2 & 16 & & \\
\hline Total & 13 & 14 & 6 & 6 & 7 & 46 & & \\
\hline
\end{tabular}


Tabel 8 memperlihatkan distribusi berdasarkan derajat leukoaraiosis dan dislipidemia serta korelasinya menggunakan uji Spearman. Penderita stroke iskemik yang tidak memiliki dislipidemia hanya terdapat 1 sampel dengan derajat leukoaraiosis 0 dan penderita stroke iskemik dengan dislipidemia lebih banyak memiliki derajat leukoaraiosis 1 yaitu sebanyak 7 $(36,8 \%)$ sampel. Hasil analisis korelasi diperoleh nilai $\mathrm{P}$ sebesar $0,185(>0,05)$ maka dapat disimpulkan bahwa tidak ada korelasi yang bermakna antara derajat leukoaraiosis dengan dislipidemia.

Tabel 9 memperlihatkan distribusi berdasarkan derajat leukoaraiosis dan derajat klinis serta korelasinya menggunakan uji Spearman. Penderita stroke iskemik dengan derajat leukoaraiosis $0,1,3$ dan 4 sama-sama lebih banyak memiliki derajat klinis sedang yaitu masing-masing sebanyak 6 $(46,2 \%), 9(64,3 \%), 3(50 \%)$ dan 6
$(85,7 \%)$ sampel, penderita stroke iskemik dengan derajat leukoaraiosis 2 memiliki derajat klinis ringan dan sedang yang sama yaitu masing-masing sebanyak 3 (50\%) sampel. Hasil analisis korelasi diperoleh nilai $\mathrm{P}$ sebesar $0,537(>0,05)$ maka dapat disimpulkan bahwa tidak ada korelasi yang bermakna antara derajat leukoaraiosis dengan derajat klinis.

Hasil penelitian didapatkan jumlah sampel laki-laki sebanyak 24 orang $(52,2 \%)$ dan perempuan 22 orang $(47,8 \%)$ yang mengalami stroke iskemik. Karakteristik sampel ini sesuai dengan penelitian Barker-Collo et al pada tahun 2015 yang menyatakan seiring waktu, beban global stroke telah meningkat baik untuk pria maupun wanita, tetapi peningkatannya lebih besar pada pria, salah satu penjelasan yang mungkin untuk ini adalah perbedaan tingkat merokok, laki-laki memiliki prevalensi merokok yang jauh lebih besar daripada perempuan (Barker-Collo et al., 2015).

Tabel 8. Korelasi derajat leukoaraiosis dan dislipidemia

\begin{tabular}{ccccccccc}
\hline \multirow{2}{*}{ Dislipidemia } & 0 & 1 & 2 & 3 & 4 & \multirow{2}{*}{ Total } & \multirow{2}{*}{ Nilai P } & \multirow{2}{*}{ Nilai $\mathrm{r}$} \\
\hline Tidak ada & 1 & 0 & 0 & 0 & 0 & 1 & & \\
Ada & 4 & 7 & 2 & 2 & 4 & 19 & 0,185 & \multirow{2}{*}{0,309} \\
Total & 5 & 7 & 2 & 2 & 4 & 20 & & \\
\hline
\end{tabular}

Tabel 9. Korelasi derajat leukoaraiosis dan derajat klinis

\begin{tabular}{cccccccc}
\hline \multirow{2}{*}{ Derajat leukoaraiosis } & \multicolumn{5}{c}{ Derajat Klinis } & Nilai P & Nilai r \\
& Ringan & Sedang & Berat & $\begin{array}{c}\text { Sangat } \\
\text { Berat }\end{array}$ & Total & & \\
\hline Derajat 0 & 5 & 6 & 1 & 1 & 13 & & \\
Derajat 1 & 4 & 9 & 1 & 0 & 14 & & \\
Derajat 2 & 3 & 3 & 0 & 0 & 6 & 0,537 & 0,093 \\
Derajat 3 & 1 & 3 & 2 & 0 & 6 & & \\
Derajat 4 & 1 & 6 & 0 & 0 & 7 & & \\
Total & 14 & 27 & 4 & 1 & 46 & & \\
\hline
\end{tabular}


Rentang usia stroke iskemik paling banyak terjadi pada umur 51-60 sebanyak 16 orang $(34,8 \%)$. Karakteristik sampel ini sesuai dengan penelitian Ovbiagele and Nguyen-Huynh pada tahun 2011 yang menyatakan bahwa Insiden stroke meningkat pesat seiring bertambahnya usia, dua kali lipat untuk setiap dekade setelah usia 55 tahun. Hal ini dikarenakan arteri kita secara alami menjadi lebih sempit dan lebih keras seiring bertambahnya usia (Ovbiagele and Nguyen-Huynh, 2011).

Penderita stroke iskemik yang memiliki hipertensi tidak terkontrol sebanyak 30 orang $(65,2 \%)$, DM tidak terkontrol sebanyak $16 \quad(34,8 \%)$ dan dislipidemia tidak terkontrol sebanyak 19 orang $(41,3 \%)$. Karakteristik sampel ini sesuai dengan beberapa penelitian yang ada, salah satunya adalah penelitian yang dilakukan oleh Zafar et al pada tahun 2016 yang menyatakan bahwa hipertensi adalah faktor risiko yang paling sering diidentifikasi pada penderita stroke iskemik (Zafar et al., 2016).

Pada tabel 4 memperlihatkan hasil analisis dengan uji Spearman bahwa tidak ada korelasi bermakna $(\mathrm{p}>0,05)$ antara derajat leukoaraiosis dengan jenis kelamin pada pasien stroke iskemik. Hal ini sesuai dengan penelitian Vedala et al pada tahun 2019 yang menyatakan bahwa keparahan leukoaraiosis tidak berhubungan secara bermakna dengan jenis kelamin (Vedala et al., 2019). Terdapat penelitian yang manyatakan bahwa tingkat keparahan leukoaraiosis lebih besar pada wanita yang lebih tua, hal tersebut mungkin disebabkan karena angka harapan hidup wanita yang lebih panjang daripada pria, seperti yang diketahui bahwa keparahan leukoaraiosis meningkat seiring bertambahnya usia. Setelah dilakukan penyesuaian kelompok usia didapatkan tidak ada hubungan antara leukoaraiosis dan jenis kelamin. Tidak ditemukan bukti yang mendukung hipotesis bahwa wanita memiliki kerentanan yang lebih besar terhadap iskemia materi putih dibandingkan pria (Simoni et al., 2012).

Pada tabel 5 memperlihatkan hasil analisis dengan uji Spearman bahwa ada korelasi bermakna $(\mathrm{p}<0,05)$ dengan kekuatan korelasi sedang dan searah dengan nilai (r) 0,515 antara derajat leukoaraiosis dengan kelompok umur pada pasien stroke iskemik. Hal ini sesuai dengan penelitian Vedala et al pada tahun 2019 yang menyatakan bahwa keparahan leukoaraiosis berhubungan secara bermakna dengan usia (Vedala et al., 2019). Dengan penuaan, arteri kehilangan elastisitas karena akumulasi plak aterosklerotik, amiloid, dan hialinisasi, yang menyebabkan iskemia dan gliosis (Marek et al., 2018). Bertambahnya usia mungkin merupakan faktor risiko terpenting untuk mengembangkan leukoaraiosis, alasan leukoaraiosis sering juga disebut sebagai penyakit materi putih terkait usia. Meskipun leukoaraiosis adalah fenomena patologis, sampai batas tertentu penyakit ini merupakan bagian dari proses penuaan normal. Namun, tidak jelas pada usia berapa penyakit materi putih mulai berkembang, dan data yang tepat tentang tingkat penyakit yang dapat dianggap normal pada usia tertentu tidak ada. Sebagian besar penelitian menunjukkan bahwa setidaknya beberapa lesi materi putih dapat muncul setelah usia 50-65 tahun. Tidak diragukan lagi bahwa leukoaraiosis adalah penemuan yang sangat umum pada orang tua dan menjadi lebih umum dan lebih parah dengan bertambahnya usia (Grueter and Schulz, 2012).

Pada tabel 6 memperlihatkan hasil analisis dengan uji Spearman bahwa tidak ada korelasi bermakna ( $p>0,05)$ antara derajat leukoaraiosis dengan hipertensi 
pada pasien stroke iskemik. Namun terlihat kecenderungan bahwa pasien dengan hipertensi tidak terkontrol memiliki derajat leukoaraiosis yang lebih berat, sedangkan pasien tanpa hipertensi memiliki derajat leukoaraiosis yang lebih ringan. Sebagian besar penelitian berdasarkan komunitas menggambarkan bahwa hipertensi tidak hanya berkorelasi dengan timbulnya leukoaraiosis tetapi juga progresifitasnya. Pasien hipertensi, terutama pasien hipertensi kronis, terjadi penebalan dinding bagian dalam dan degenerasi hialin pada arteriol intrakranial dan arteri perforasi dalam. Karena kurangnya arteri perforasi dalam dan sirkulasi kolateral, materi putih terluka, dan kemudian terjadi leukoaraiosis (Yang et al., 2020). Hipertensi sangat terkait dengan penyakit materi putih dan mungkin merupakan faktor risiko paling penting yang dapat dimodifikasi. Studi tentang penyakit materi putih jelas menunjukkan bahwa hipertensi memainkan peran penting dalam perkembangan leukoaraiosis, dengan peningkatan tekanan darah sistolik dan diastolik keduanya tampaknya relevan (Grueter and Schulz, 2012). Penderita hipertensi yang tidak terkontrol memiliki derajat leukoaraosis yang lebih berat dibandingkan dengan penderita hipertensi yang terkontrol (Kuo and Lipsitz, 2004).

Pada tabel 7 memperlihatkan hasil analisis dengan uji Spearman bahwa tidak ada korelasi bermakna $(p>0,05)$ antara derajat leukoaraiosis dengan DM pada pasien stroke iskemik. Sekitar $40 \%$ dari tinjauan studi melaporkan hubungan yang signifikan secara statistik antara DM dan leukoaraiosis. DM jangka panjang dan kontrol glikemik yang buruk dikaitkan dengan leukoaraiosis parah. Studi menggunakan teknik MRI inovatif, seperti pencitraan tensor difusi (DTI), melaporkan hubungan yang signifikan antara perubahan mikro struktur materi putih dan DM. Hasil ini mungkin karena teknik pencitraan yang lebih sensitif dan canggih yang baru-baru ini digunakan untuk mempelajari tingkat leukoaraiosis. Namun, karena metodologi heterogen yang digunakan dalam studi yang ditinjau, kesimpulan yang pasti tidak dapat ditarik (Del Bene et al., 2015).

Pada tabel 8 memperlihatkan hasil analisis dengan uji Spearman bahwa tidak ada korelasi bermakna $(p>0,05)$ antara derajat leukoaraiosis dengan dislipidemia pada pasien stroke iskemik. Hal ini sesuai dengan penelitian Vedala et al pada tahun 2019 yang menyatakan bahwa keparahan leukoaraiosis tidak berhubungan secara bermakna dengan riwayat dislipidemia (Vedala et al., 2019). Beberapa penelitian telah menemukan bahwa hiperlipidemia secara independen berhubungan dengan penurunan keparahan leukoaraiosis pada orang tua atau pasien dengan stroke iskemik. Namun dalam penelitian lain, tidak ada perbedaan statistik antara hiperlipidemia dan leukoaraiosis (Ke et al., 2018).

Pada 10adio 9 memperlihatkan hasil analisis dengan uji Spearman bahwa tidak ada korelasi bermakna $(p>0,05)$ antara derajat leukoaraiosis dengan derajat klinis pada pasien stroke iskemik. Hal ini sesuai dengan penelitian yang pernah dilakukan Marek et al pada tahun 2019 dimana juga menyebutkan bahwa tidak ada korelasi yang ditunjukkan antara luas leukoaraiosis dan keparahan stroke iskemik yang diukur dengan skala NIHSS. Namun tidak sesuai dengan penelitian yang pernah dilakukan Marek et al sebelumnya pada tahun 2017, Helenius and Henninger pada tahun 2015 dan Arsava et al pada tahun 2009 yang menyatakan bahwa luas leukoaraiosis berkorelasi dengan keparahan stroke iskemik. Hal ini mungkin disebabkan 
karena metodologi yang 11adiograph, perbedaan modalitas yang digunakan, jumlah sampel yang berbeda, serta lokasi dan luas infark yang berbeda yang mungkin dapat mempengaruhi keparahan derajat klinis pasien. Kelemahan dari penelitian ini adalah sampel diambil dari RSUP Dr. Wahidin Sudirohusodo Makassar yang merupakan RS rujukan terakhir sehingga ada kemungkinan 11adiogra pasien sudah mendapatkan penanganan awal di RS sebelumnya sehingga dapat mempengaruhi tekanan darah, kadar gula darah, kadar lipid maupun skor NIHSS pada saat pasien masuk RSUP Dr. Wahidin Sudirohusodo Makassar.

\section{PENUTUP}

1. Tidak ada korelasi yang bermakna antara derajat leukoaraiosis berdasarkan CT Scan kepala dengan keparahan stroke berdasarkan derajat klinis pada pasien stroke iskemik.

2 Terdapat korelasi yang bermakna dengan kekuatan sedang dan searah antara umur dengan derajat leukoaraiosis pasien stroke iskemik.

3. Tidak ada korelasi yang bermakna antara hipertensi dengan derajat leukoaraiosis pasien stroke iskemik. Namun terlihat kecenderungan bahwa pasien dengan hipertensi tidak terkontrol memiliki derajat leukoaraiosis yang lebih berat.

4. Tidak ada korelasi yang bermakna antara jenis kelamin, DM dan dislipidemia dengan derajat leukoaraiosis pasien stroke iskemik.

\section{Ucapan Terima Kasih}

Terima kasih kepada Kepala Departemen Radiologi Fakultas Kedokteran Universitas Hasanuddin yaitu Prof. Dr. dr. Bachtiar Murtala, Sp.Rad(K), Kepala Program Studi Radiologi Fakultas
Kedokteran Universitas Hasanuddin yaitu dr. Sri Asriyani, Sp.Rad(K), M.Med.Ed., Kepala Instalasi Radiologi Fakultas Kedokteran Universitas Hasanuddin yaitu dr. Eny Sanre, Sp.Rad., M.Kes., seluruh staf pengajar Departemen Radiologi Fakultas Kedokteran Universitas Hasanuddin, keluarga, seluruh residen radiologi Universitas Hasanuddin dan 1 1adiographer Instalasi Radiologi RSUP dr. Wahidin Sudirohusodo.

\section{DAFTAR PUSTAKA}

Arsava E.M. et al. (2009). 'Severity of leukoaraiosis correlates with clinical outcome after ischemic stroke', Neurology, 72(16), pp. 1403-1410. doi: 10.1212/WNL.0b013e3181a18823.

Barker-Collo S. et al. (2015). 'Sex differences in stroke incidence, prevalence,mortality and disability-adjusted life years: Results from the global burden of disease study 2013', Neuroepidemiology, 45(3), pp. 203-214. doi: 10.1159/000441103.

Del Bene A. et al. (2015). 'Is type 2 diabetes related to leukoaraiosis? an updated review', Acta Neurologica Scandinavica, 132(3), pp. 147-155. doi: 10.1111/ane.12398.

Grueter B.E and Schulz U.G. (2012). 'Agerelated cerebral white matter disease (Leukoaraiosis): A review', Postgraduate Medical Journal, 88(1036), pp. 79-87. doi: 10.1136/postgradmedj-2011-130307.

Helenius J and Henninger N. (2015). 'Leukoaraiosis Burden Significantly Modulates the Association between Infarct Volume and National Institutes of Health Stroke Scale in Ischemic Stroke', Stroke, 46(7), pp. 1857-1863. doi: 10.1161/STROKEAHA.115.009258.

Ke D. et al. (2018). 'Hypertriglyceridemia Is Associated with Reduced Leukoaraiosis Severity in Patients with a Small Vessel Stroke', Behavioural neurology, 2018, p. 1361780. doi: 10.1155/2018/1361780.

Kuo H.K and Lipsitz L.A. (2004). 'Cerebral white matter changes and geriatric 
syndromes: Is there a link?', Journals of Gerontology - Series A Biological Sciences and Medical Sciences, 59(8), pp. $\quad 818-826 . \quad$ doi: 10.1093/gerona/59.8.m818.

Lyden P. (2017). 'Using the National Institutes of Health Stroke Scale', Stroke, 48(2), pp. 513-519. doi: 10.1161/STROKEAHA.116.015434.

Marek M. et al. (2017). 'Leukoaraiosis and its correlation with a stroke.'

Marek M. et al. (2018). 'Leukoaraiosis - New concepts and modern imaging', Polish Journal of Radiology, 83, pp. e76-e81. doi: 10.5114/pjr.2018.74344.

Marek M. et al. (2019). 'Relationship between stroke severity, extensity of leukoaraiosis, and brain atrophy in patients with ischaemic stroke', Polish Journal of Radiology, 84, pp. e80-e85. doi: 10.5114/pjr.82917.

Ovbiagele B and Nguyen-Huynh M.N. (2011). 'Stroke Epidemiology: Advancing Our Understanding of Disease Mechanism and Therapy', Neurotherapeutics, 8(3), pp. 319-329. doi: 10.1007/s13311-011-0053-1.

Sacco R.L. et al. (2013). 'An updated definition of stroke for the 21st century: A statement for healthcare professionals from the American heart association/American stroke association', Stroke, 44(7), pp. 2064 2089. doi: 10.1161/STR.0b013e318296aeca.

Simoni M. et al. (2012). 'Age- and sexspecific rates of leukoaraiosis in TIA and stroke patients population-based study', Neurology, 79(12), pp. 1215-1222. doi: 10.1212/WNL.0b013e31826b951e.

Vedala K. et al. (2019). 'Factors Associated with Leukoaraiosis Severity in Acute Stroke Patients', Journal of Stroke and Cerebrovascular Diseases, 28(7), pp. 1897-1901. doi: 10.1016/j.jstrokecerebrovasdis.2019.04. 003.

Yang K. et al. (2020). 'Abnormal blood pressure circadian rhythms are relevant to cerebral infarction and Leukoaraiosis in hypertensive patients', $B M C$ Neurology, 20(1), pp. 1-10. doi: 10.1186/s12883-020-1626-6.

Zafar A. et al. (2016). 'Risk factors and subtypes of acute ischemic stroke: A study at king fahd hospital of the university', Neurosciences, 21(3), pp. 246-251. doi: 